\title{
Patient satisfaction following nipple reconstruction incorporating autologous costal cartilage
}

\author{
Joan E Lipa MD MSc FRCSC FACS, Patrick D Addison MBChB MD FRCSPlast, Peter C Neligan MB FACS FRCSC
}

\begin{abstract}
JE Lipa, PD Addison, PC Neligan. Patient satisfaction following nipple reconstruction incorporating autologous costal cartilage. Can J Plast Surg 2008;16(2):85-88.
\end{abstract}

BACKGROUND: Nipple-areolar reconstruction completes postmastectomy breast reconstruction. Many techniques for nipple reconstruction have been described, and each has their advocates and critics. One of the frequent failings of most designs is loss of nipple projection with time.

OBJECTIVES: To determine the effect of including autologous costal cartilage on patient satisfaction with their nipple reconstruction.

METHODS: Sixty-eight patients were identified who had undergone fishtail flap nipple reconstruction following autologous free flap breast reconstruction between 1990 and 2004. Qualitative questionnaires, using Likert scales, were sent to each patient to specifically assess their satisfaction with their nipple reconstruction.

RESULTS: Of 26 respondents (mean \pm SEM follow-up period $3.7 \pm 3.6$ years), 13 had undergone nipple reconstruction incorporating costal cartilage banked at the time of initial breast reconstruction, and the other 13 had no cartilage in their nipple reconstructions. While both groups would opt for nipple reconstruction again, patients with cartilage grafts incorporated into their reconstructions had overall satisfaction ratings 1.92 grades higher on average (not significant, $\mathrm{P}=0.12$ ) than those without. This difference increased to 3.2 grades when the satisfaction of the patient's partner was taken into account $(\mathrm{P}<0.05)$. Improved satisfaction corresponded to higher scores for volume, consistency, texture, and particularly for projection and contour of the nipple $(\mathrm{P}<0.05)$. Although nipple morphology changed over time, there was a trend toward improved stability in the cartilage group.

CONCLUSIONS: Patient satisfaction with nipple reconstruction can be improved by incorporating costal cartilage beneath the skin flaps. Superior contour and projection are sustained over time.

Key Words: Autologous cartilage; Nipple reconstruction

\section{Satisfaction des patientes à l'endroit de mamelons reconstruits avec du cartilage costal autologue}

HISTORIQUE : La reconstruction du mamelon et de l'aréole vient compléter la reconstruction mammaire après la mastectomie. De nombreuses techniques de reconstruction du mamelon ont été décrites et chacune a ses défenseurs et des détracteurs. L'une des lacunes fréquentes de la plupart des techniques est la perte éventuelle de projection du mamelon.

OBJECTIF : Déterminer l'effet de l'inclusion de cartilage costal autologue sur la satisfaction des patientes devant subir une reconstruction du mamelon. MÉTHODES : Soixante-huit patientes ont été recensées. Elles avaient subi une reconstruction du mamelon par lambeau en queue de poisson après une reconstruction mammaire par lambeau libre autologue entre 1990 et 2004. Un questionnaire qualitatif doté d'échelles de Likert a été envoyé à chaque patiente pour évaluer spécifiquement sa satisfaction à l'endroit de la reconstruction du mamelon.

RÉSULTATS : Parmi 26 répondantes (période de suivi moyen [ \pm ÉTM] 3,7 $\pm 3,6$ ans), 13 avaient subi une reconstruction du mamelon intégrant du cartilage costal au moment de la reconstruction mammaire initiale et les 13 autres ne présentaient pas de cartilage dans la reconstruction de leur mamelon. Les deux groupes opteraient de nouveau pour la reconstruction du mamelon, mais les patientes porteuses de greffes de cartilage intégrées au mamelon reconstruit présentaient en moyenne des cotes de satisfaction globale de 1,92 point supérieure (non significatif, $\mathrm{p}=0,12$ ) comparativement aux autres. Cette différence passait à 3,2 points lorsque l'on tenait compte de la satisfaction du partenaire de la patiente $(\mathrm{p}<0,05)$. Le degré de satisfaction était proportionnel au score obtenu pour les paramètres du volume, de la consistance, de la texture et particulièrement pour la projection et le contour du mamelon $(\mathrm{p}<0,05)$. Bien que la morphologie du mamelon ait changé avec le temps, on a noté une tendance à une meilleure stabilité dans le groupe dont la reconstruction comportait du cartilage. CONCLUSION : La satisfaction des patientes à l'égard de la reconstruction du mamelon peut être améliorée par l'intégration de cartilage costal sous le lambeau cutané. Les aspects du contour et de la projection, qui sont ainsi améliorés, résistent mieux avec le temps.
$\mathrm{M}$ any women now opt for nipple-areolar reconstruction following mastectomy and breast mound reconstruction to help restore body image more completely, but many reconstructions are unsatisfactory (1). Numerous techniques, using a variety of geometric designs, have been reported and reviewed (2-9). Each aims to achieve a natural shape with maintenance of projection over time, and minimal donor site morbidity. The most popular techniques benefit from simplicity, reliability and reproducibility. One significant challenge, however, is in achieving and maintaining nipple projection while allowing for primary closure of the donor site. In doing so, flattening of the breast mound at the site of maximal projection should be avoided. The fact that so many techniques have been described demonstrates that none has been entirely successful in achieving these objectives. A comparison of three common techniques reported a loss of nipple projection of between $40 \%$ and $74 \%$ over time (10). In general, nipple reconstruction using these techniques requires a degree of overcorrection in anticipation of eventual loss of projection. This makes symmetry harder to achieve and contributes to donor site morbidity.

Nipple reconstruction often makes use of local adipocutaneous flaps with direct closure or skin grafting of the donor sites. Examples of the former include a variety of bilobed and trilobed flaps, including the skate flap. These flaps have no intrinsic 'scaffold' and are especially prone to flattening. To maintain long-term nipple projection, larger flaps have been 


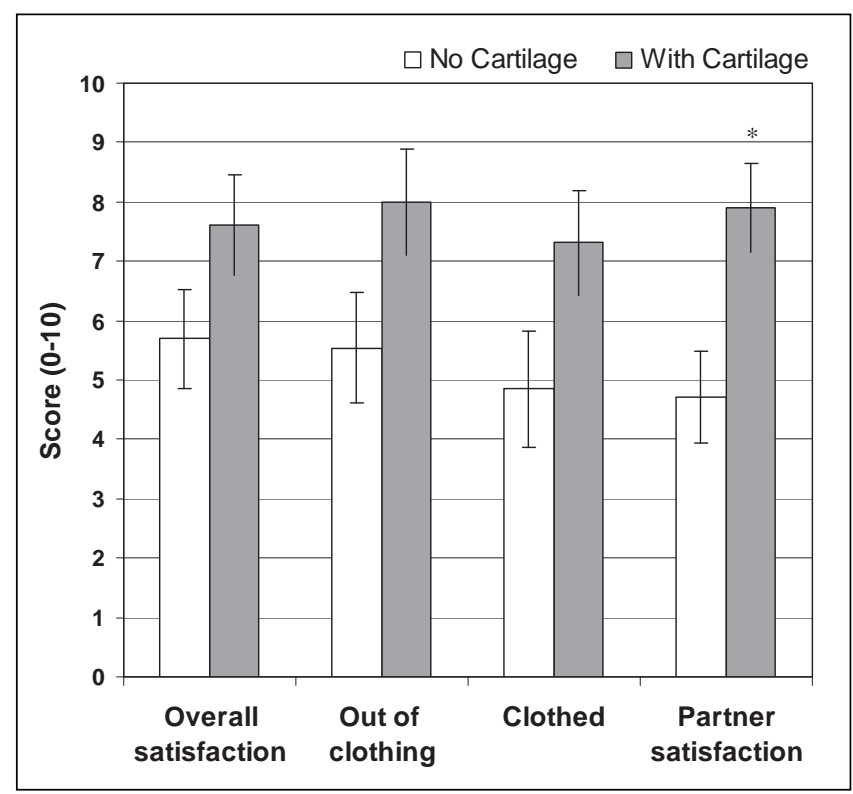

Figure 1) Patient and partner satisfaction with nipple reconstruction. Graph shows score on Likert scale for satisfaction (mean \pm SEM). Only partner satisfaction reached statistical significance. $* P<0.05$

designed but are limited by increasing difficulty in donor site closure. Additionally, larger flaps have a tendency to flatten the donor site and, therefore, the point of maximal projection of the breast, reducing the overall aesthetic result.

A variety of tissues can be grafted to the breast mound to create the new nipple. These have included the contralateral heminipple, or if this is inadequate, oral mucosa, earlobe or labia tissue, and toe pulp can be used. A secondary donor site is not ideal, however, and graft survival is unpredictable and often incomplete. The use of a tie-over dressing on a graft may also contribute to loss of projection.

Several synthetic implants such as silicone, Alloderm (Lifecell Corporation, USA) (11) and artificial bone (12) have been placed beneath the skin flap to augment projection, but these foreign materials suffer from an increased risk of extrusion or absorption, and may encourage infection and wound healing complications. Recently, a tissue engineered construct has been described, but this technique is relatively time-consuming and complex, especially because other autologous tissue is readily available (13).

Autologous auricular cartilage grafts have been used, but with inconsistent maintenance of shape and projection (14-16). Autologous rib cartilage grafts, however, present an alternative that need not carry additional donor site morbidity and avoids some of the potential complications associated with synthetic materials (17).

The internal mammary artery and vein are increasingly popular donor vessels for free flap breast mound reconstruction, allowing more of the flap bulk to be placed medially on the chest wall. Access to these vessels requires excision of a segment of costal cartilage. Instead of discarding this cartilage, it can be 'banked' intraoperatively into a subcutaneous pocket, from where it can be harvested and used to augment projection in subsequent nipple reconstruction.

The aim of the present study was to assess patient satisfaction following placement of autologous rib cartilage graft to augment nipple projection.

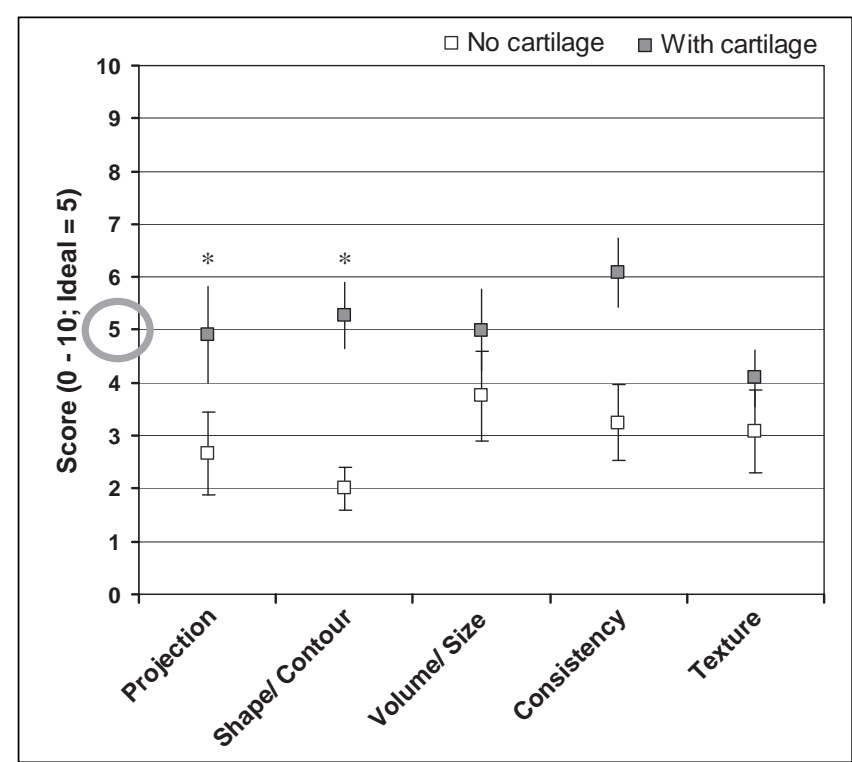

Figure 2) Patient assessment of nipple characteristics. Graph shows score on Likert scale for satisfaction (mean \pm SEM). A score of 5 approximates the patient's concept of ideal, and a score greater than 5 suggests a degree of overcorrection. $* P<0.05$

\section{METHODS}

A group of 68 patients who had undergone nipple reconstruction following free flap breast reconstruction between 1990 and 2004 using fishtail adipocutaneous flaps were retrospectively identified from case records. Each was sent an outcome questionnaire, using Likert scoring scales (scale of 0 to 10), relating specifically to their nipple reconstruction. The data obtained from the respondents were collected and analysis was expressed as the mean \pm SEM. Microsoft Excel (Microsoft Corporation, USA) was used to perform the statistical analysis by ANOVA with significance set at $\mathrm{P}<0.05$.

\section{RESULTS}

Of the 68 patients identified for inclusion in the study, 26 responded to the questionnaire (38\%). Of these, one-half had undergone nipple reconstruction with the fishtail flap and autologous rib cartilage. The remaining 13 patients had undergone reconstruction with fishtail flaps but without cartilage. The mean follow-up was $3.7 \pm 3.6$ years (range 0.5 to 13.5 years). No complications with respect to cartilage extrusion, exposure or infection were recorded among these patients.

Patient satisfaction is summarized in Figure 1. Overall, patients rated their satisfaction with the reconstruction more highly when a cartilage graft was used with a mean \pm SEM score $7.6 \pm 2.9$ versus $5.7 \pm 3.0$ for no cartilage graft. This held true both in and out of clothing. Interestingly, the patient's partner also rated the reconstruction more highly when cartilage was used ( $7.9 \pm 2.8$ versus $4.7 \pm 2.77$ for no cartilage).

With respect to the characteristics of the reconstructed nipple, there was again a significant improvement in patient satisfaction when cartilage had been used in the reconstruction and the new nipple more closely approximated the patients' perception of an ideal nipple (Figure 2). Subjectively, patient satisfaction with the characteristics of the reconstructed nipple was near their ideal in terms of projection, shape, contour, size and volume when cartilage was used. Such reconstructions, however, produced a nipple that was, in some cases, thought to 


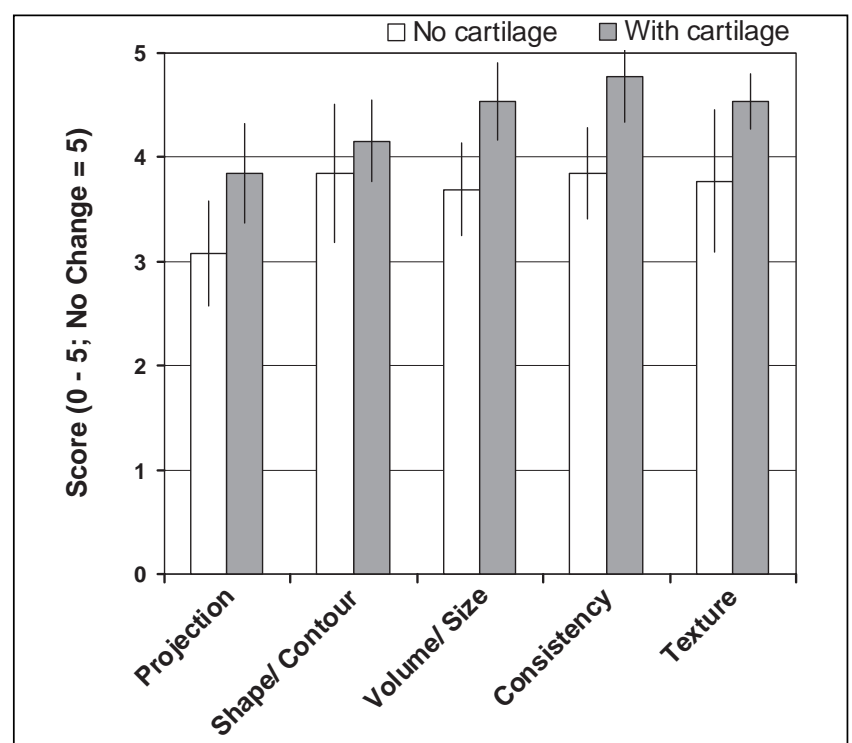

Figure 3) Stability of nipple characteristics over time. Graph shows score on Likert scale for change in satisfaction over time (mean \pm SEM). A score of 5 suggests no change over time, and a score less than 5 suggests deterioration with time. No result was statistically significant

be too firm. In contrast, reconstructions without cartilage fell short of the patients' ideals in all of the variables assessed.

When patients were asked to assess whether they thought that the characteristics of their reconstructed nipple had changed or remained stable from the time of reconstruction to the present, in all aspects, nipple reconstructions using cartilage graft appear to maintain their characteristics better than those without, but the differences were nonsignificant (Figure 3).

\section{DISCUSSION}

The most challenging component of nipple reconstruction is the maintenance of long-term nipple projection $(10,18,19)$. Most techniques for nipple reconstruction involve the use of local or grafted soft tissue. These often suffer from inadequate primary projection or secondary flattening (Figure 4). Factors that predispose to loss of nipple projection include inadequacy of available subcutaneous tissue beneath the flaps, poorly designed flaps with scars that contract and pull the nipple inward, and external pressure from dressings or bras. Synthetic endoprostheses such as silicone have been advocated as a means to maintain projection $(20,21)$, but these are associated with several complications, including infection, allergy and extrusion (22). Some of these complications can be avoided by the use of autologous tissues. These include fat grafting (23) and rolled auricular cartilage $(16,24)$. Brent (14) and Brent and Bostwick (15) first proposed the use of auricular cartilage, and Guerra et al (17) recently described the use of autologous rib cartilage. Although the use of auricular cartilage has been successful, it necessitates a secondary donor site. The advantage of rib cartilage is that it is harvested at the time of free flap breast reconstruction when the internal mammary vessels are exposed. This piece of cartilage, which would otherwise be discarded, can be banked within the breast mound for later use. At the time of nipple reconstruction, the cartilage is retrieved and shaped before being secured to the deep surface of the flaps used to create the new nipple (Figure 5).

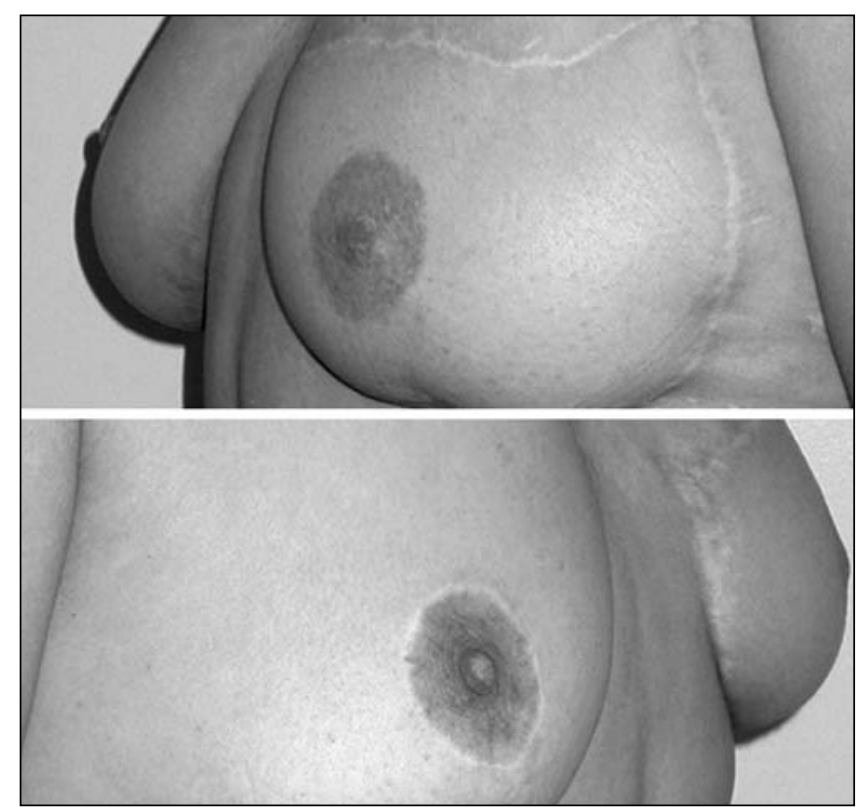

Figure 4) Left nipple reconstruction without cartilage has flattened. An illusion of projection has been achieved by tattooing. Figure used with permission of Joan Lipa
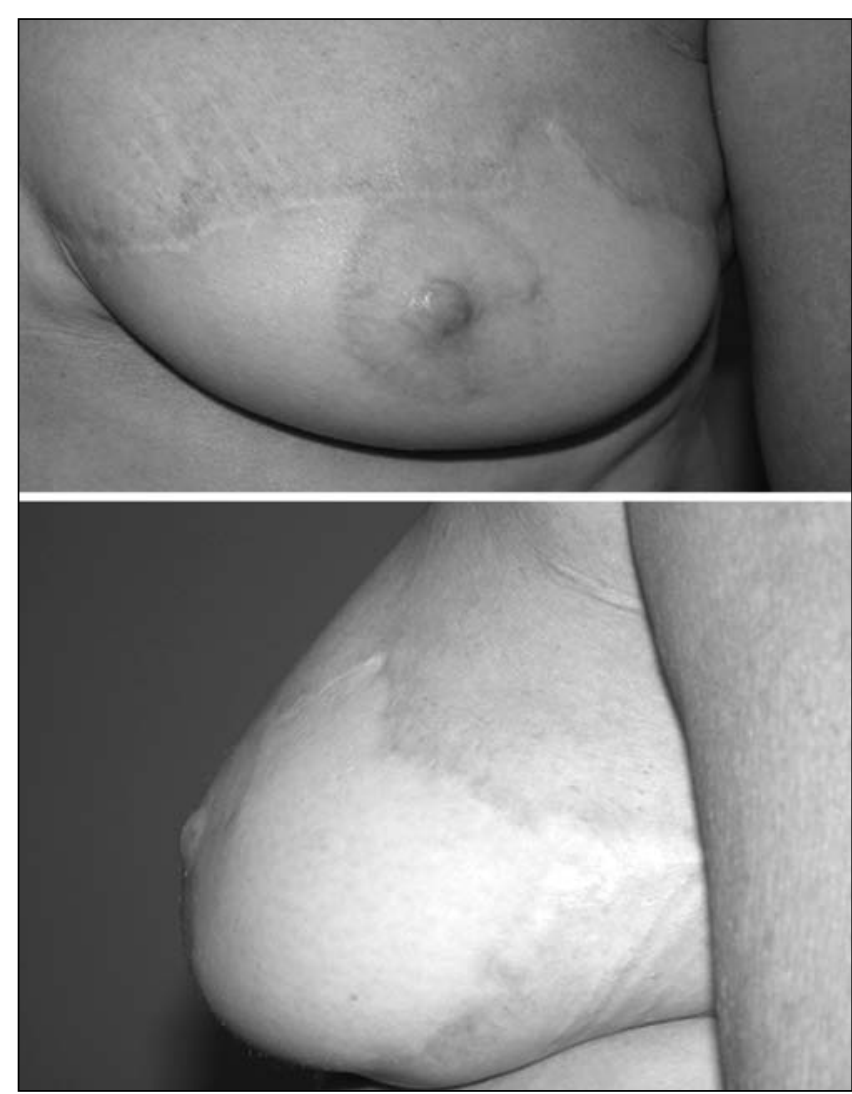

Figure 5) Left nipple reconstruction with cartilage, demonstrating maintenance of projection. Figure used with permission of Joan Lipa

The technique used in our patients is essentially the same as that described by Guerra et al (17), with a few modifications. The cartilage is consistently banked beneath the mastectomy 


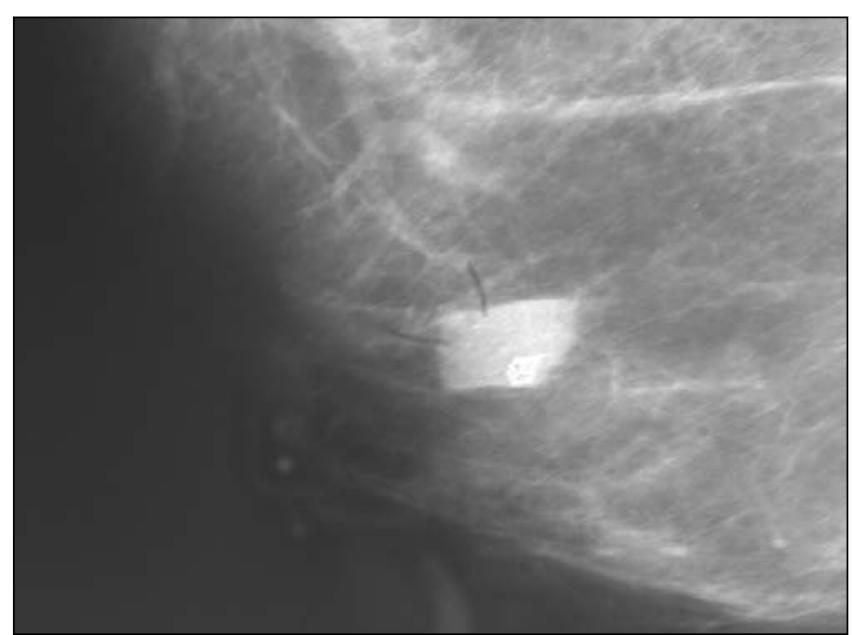

Figure 6) Mammogram showing banked cartilage appearing as a mass within the reconstructed breast. Figure used with permission of Joan Lipa

flaps, either in the 06:00 position in an immediate reconstruction or at a lateral position in a delayed reconstruction, to permit easy access at the time of nipple reconstruction through the old scar. The cartilage is carved to the desired shape at the time of nipple reconstruction; a pea-sized ball on a flat base minimizes the risk of the cartilage receding into the breast mound. Finally, the cartilage is physically secured to the skin flaps to prevent migration and rotation, and the skin is closed over with absorbable sutures. There were no recorded complications with the cartilage grafts. Although at the time of the study nipple reconstruction was performed exclusively with fishtail flaps to maintain consistency to allow for comparison

\section{REFERENCES}

1. Jabor MA, Shayani P, Collins DR Jr, Karas T, Cohen BE. Nippleareola reconstruction: satisfaction and clinical determinants. Plast Reconstr Surg 2002;110:457-63.

2. Farhadi J, Maksvytyte GK, Schaefer DJ, Pierer G, Scheufler O. Reconstruction of the nipple-areola complex: An update. J Plast Reconstr Aesthet Surg 2006;59:40-53.

3. Shestak KC, Nguyen TD. The double opposing periareola flap: A novel concept for nipple-areola reconstruction. Plast Reconstr Surg 2007;119:473-80.

4. Eo S, Kim SS, Da Lio AL. Nipple reconstruction with C-v flap using dermofat graft. Ann Plast Surg 2007;58:137-40.

5. Schoeller T, Schubert HM, Pulzl P, et al. Nipple reconstruction using a modified arrow flap technique. Breast 2006;15:762-8.

6. Germano D, De Biasio F, Piedimonte A, et al. Nipple reconstruction using the fleur-de-lis flap technique. Aesthetic Plast Surg 2006;30:399-402.

7. Gamboa-Bobadilla GM. Nipple reconstruction: The top hat technique. Ann Plast Surg 2005;54:243-6.

8. Rubino C, Dessy LA, Posadinu A. A modified technique for nipple reconstruction: The 'arrow flap'. Br J Plast Surg 2003;56:247-51.

9. Losken A, Mackay GJ, Bostwick J 3rd. Nipple reconstruction using the C-V flap technique: A long-term evaluation. Plast Reconstr Surg 2001;108:361-9.

10. Shestak KC, Gabriel A, Landecker A, Peters S, Shestak A, Kim J. Assessment of long-term nipple projection: A comparison of three techniques. Plast Reconstr Surg 2002;110:780-6.

11. Nahabedian MY. Secondary nipple reconstruction using local flaps and AlloDerm. Plast Reconstr Surg 2005;115:2056-61.

12. Yanaga H. Nipple-areola reconstruction with a dermal-fat flap: Technical improvement from rolled auricular cartilage to artificial bone. Plast Reconstr Surg 2003;112:1863-9. of outcomes, we presently also use the arrowhead $(\mathrm{C}-\mathrm{V})$ flaps when larger nipples are reconstructed, with similar results.

Banked cartilage, as well as cartilage within the reconstructed nipple, can be mistaken for cancer recurrence on palpation, and on radiography or ultrasound, and it is imperative that both the patient and oncologist be aware of its presence and position to avoid unnecessary worry or investigations (Figure 6).

All of the patients in the present study underwent breast mound reconstruction with the free transverse rectus abdominal myocutaneous or deep inferior epigastric perforator flaps. It is possible that these results may not be generalized to other forms of free flap breast reconstruction, because the skin overlying the gluteal artery perforator flaps may be thicker and less able to cover a cartilage graft (17).

This is the first study to assess patient satisfaction following nipple reconstruction with or without autologous rib cartilage graft. The percentage of respondents was low (38\%), and the present study had to assume that the respondents represented the population as a whole. It could be argued that the nonrespondents were more likely to be dissatisfied with their results and, therefore, not willing to take part in the study. Alternatively, an unhappy patient may be more likely to express her dissatisfaction by completing the questionnaire. We accept that there may be a bias among the respondents. The results nonetheless suggest that patients and their partners are more satisfied with reconstructions incorporating costal cartilage and that the morphology of the reconstructed nipple in these patients more closely approximates the patient's ideal and is better maintained over time.

ACKNOWLEDGEMENTS: The authors would like to acknowledge the assistance of Dr Kyle N Cowan, PhD MD, a former medical student on the Plastic Surgery Service at the University of Toronto, Toronto, Ontario.

13. Cao YL, Lach E, Kim TH, Rodríguez A, Arévalo CA, Vacanti CA. Tissue-engineered nipple reconstruction. Plast Reconstr Surg 1998;102:2293-8.

14. Brent B. Nipple-areola reconstruction following mastectomy: An alternative to the use of labial and contralateral nipple-areolar tissues. Clin Plast Surg 1979;6:85-92.

15. Brent B, Bostwick J. Nipple-areola reconstruction with auricular tissues. Plast Reconstr Surg 1977;60:353-61.

16. Tanabe HY, Tai Y, Kiyokawa K, et al. Nipple-areola reconstruction with a dermal-fat flap and rolled auricular cartilage. Plast Reconstr Surg 1997;100:431-8.

17. Guerra AB, Khoobehi K, Metzinger SE, Allen RJ. New technique for nipple areola reconstruction: Arrow flap and rib cartilage graft for long-lasting nipple projection. Ann Plast Surg 2003;50:31-7.

18. Kroll SS, Reece GP, Miller MJ, et al. Comparison of nipple projection with the modified double-opposing tab and star flaps. Plast Reconstr Surg 1997;99:1602-5.

19. Few JW, Marcus JR, Casas LA, Aitken ME, Redding J. Long-term predictable nipple projection following reconstruction. Plast Reconstr Surg 1999;104:1321-4.

20. Hallock GG. Polyurethane nipple prosthesis. Ann Plast Surg 1990;24:80-5.

21. Guida CA, Picchi A, Inzirillo S. Areola and nipple reconstruction. Plast Reconstr Surg 1975;56:454-5.

22. Ward CM. The uses of external nipple-areola prostheses following reconstruction of a breast mound after mastectomy. Br J Plast Surg 1985;38:51-4.

23. Bernard RW, Beran SJ. Autologous fat graft in nipple reconstruction. Plast Reconstr Surg 2003;112:964-8.

24. Collis N, Garrido A. Maintenance of nipple projection using auricular cartilage. Plast Reconstr Surg 2000;105:2276-7. 